\title{
Effect of dietary lysine on muscle protein turnover in growing chickens
}

\author{
S Tesseraud, M Larbier, AM Chagneau, PA Geraert
}

INRA, Station de Recherches Avicoles, 37380 Nouzilly, France

(Received 11 March 1991; accepted 3 March 1992)

\begin{abstract}
Summary - Day-old male chickens were fed ad libitum isoenergetic diets containing $20 \%$ crude protein but differing in their lysine content (from 6.5 up to $11.3 \mathrm{~g} / \mathrm{kg}$ ). At 3 weeks of age, protein fractional synthesis rates in the pectoralis major muscle were determined using a large dose injection of $120 \mu \mathrm{mol}$ per $\mathrm{kg}$ body weight of $\mathrm{L}-[4-3 \mathrm{H}]$ phenylalanine. Protein gain in the pectoralis major was measured between 19 and 23 days of age. Protein breakdown was obtained by calculating the difference between protein synthesis and deposition. Weight gain varied curvilinearly with dietary lysine intake and was maximum for $11.3 \mathrm{~g}$ lysine $/ \mathrm{kg}$ of diet. in birds fed an adequate lysine intake $(10.1-11.3 \mathrm{~g} / \mathrm{kg}$ ) protein fractional synthesis and breakdown rates were $23.6-25.9$ and $17.8-19.8 \% / \mathrm{d}$ respectively. Increasing lysine supplementation in the diet resulted in an impairment of protein fractional breakdown rates. By contrast, protein fractional synthesis rates remained unchanged owing mainly to an improvement in the synthesis efficiency (kRNA), until birds were fed an adequate lysine intake. These data suggest that the growth rate reduction of chickens fed lysine deficient diets was due to alterations in both rates of protein synthesis and breakdown in skeletal muscle. A maximum protein deposition is achieved when kRNA was optimal, ie for a dietary lysine content of about $9 \mathrm{~g} / \mathrm{kg}$, a value close to the requirement.
\end{abstract}

lysine / protein synthesis / protein breakdown / chicken

Résumé - Influence de la lysine alimentaire sur le renouvellement des protéines du muscle chez le poulet de chair. Des poulets mâles à croissance rapide sont nourris ad libitum jusqu'à l'âge de 3 semaines avec des régimes isoénergétiques titrant $20 \%$ de protéines totales mais différant par leur teneur en lysine $(6,5-11,3 \mathrm{~g} / \mathrm{kg})$. Les vitesses de synthèse des protéines du muscle pectoralis major sont déterminées en utilisant la méthode de surcharge en phénylalanine tritiée (injection intraveineuse de $120 \mu \mathrm{mol} / \mathrm{kg}$ de poids vif de $\left.L-\left[4-{ }^{3} \mathrm{H}\right] \mathrm{Phe}\right)$. Le gain protéique du muscle pectoralis major est mesuré entre les $19^{\circ}$ et $23^{\circ}$ jours. La dégradation des protéines est obtenue par différence entre la vitesse de synthèse et la vitesse de dépôt protéique.

Le gain de poids varie de façon curvilinéaire avec le taux de lysine du régime alimentaire et atteint un maximum pour un apport de lysine de $11,3 \mathrm{~g} / \mathrm{kg}$ de régime. Chez les animaux nourris avec un aliment équilibré titrant entre 10,1 et $11,3 \mathrm{~g}$ de lysine/kg, les vitesses de synthèse et de dégradation des protéines sont respectivement $23,6-25,9$ et $17,8-19,8 \% /$. La supplémentation en lysine du régime entraîne une diminution des vitesses de dégradation des protéines. En revanche, les vitesses de synthèse ne sont pas modifiées pour des apports alimentaires de lysine inférieurs au besoin en raison d'une amélioration de l'efficacité de synthèse (kRNA). 
Ces données suggèrent que la baisse de la vitesse de croissance du poulet nourri avec un aliment carencé en lysine est due à des modifications des 2 composantes du renouvellement des protéines du muscle squelettique, à savoir vitesses de synthèse et de dégradation. Le dépôt protéique est maximal lorsque l'efficacité de synthèse de protéines ( $k R N A$ ) atteint sa valeur la plus élevée; la teneur en lysine du régime est alors $9 \mathrm{~g} / \mathrm{kg}$, valeur proche du besoin.

lysine / : :ynthèse des protéines / dégradation des protéines / poulet

\section{INTRODUCTION}

Protein turnover is extremely sensitive to protein intake (Waterlow, 1984; Arnal et al, 1987). First, the amount of dietary protein is known to have a major influence on the accretion of body proteins, in particular within skeletal muscle. Second, the nature and the quality of protein intake (amino acid balance) or a specific amino acid may influence protein turnover. For example, in broilers, methionine and lysine are respectively first and second limiting factors for protein synthesis in low protein diets based on cereals and soya bean meal, ie they may be provided in lower amounts than the requirements.

The chick is a convenient experimental model for the study of muscle growth because of its extremely high growth rate as compared to young rodents. However, few studies on protein synthesis and breakdown in relation with dietary amino acid imbalance have been performed in this species and controversial conclusions have been obtained. According to McDonald and Swick (1981), dietary protein depletion (protein-free diet) and repletion caused changes in breast muscle protein mass primarily through changes in the rate of protein synthesis. This observation differs from previous studies in which less severe protein depletions were introduced without any change in protein synthesis (Maruyama et al, 1978). Other studies were performed in order to determine the effect of a limiting amino acid supplementation in protein-starved chicks. Muramatsu et al (1986) showed that the addition of DLmethionine to a protein free diet significantly increased whole body protein synthesis both in terms of fractional rate and absolute amounts, whereas the fractional degradation rate was unchanged. To our knowledge, no quantitative information concerning the effect of a single amino acid imbalance on protein metabolism is available in chickens. The present work was undertaken to study the effect of lysine additions to a lysine-deficient diet but well-balanced in other amino acids on muscle protein turnover in 3-week-old chickens.

The reduction of growth performance associated with dietary essential amino acid imbalance (Larbier and Picard, 1977) could be explained by either a lower whole-body protein synthesis rate or a higher breakdown rate, or a simultaneous change in both components of protein turnover. Nitrogen balance techniques do not provide any information about these possibilities. We used a large dose of $\left[{ }^{3} \mathrm{H}\right]$ phenylalanine, previously validated in chickens (Muramatsu and Okumura, 1985), to flood the precursor pools of protein synthesis. The flooding-dose technique (McNurlan et al, 1979; Garlick et al, 1980) appears to be particularly appropriate for determining tissue or whole body protein synthesis rate in vivo, and therefore to minimize the error inherent to pro- 
tein breakdown calculation. The capacity for protein synthesis, ie RNA/protein ratio $\left(C_{\mathrm{s}}\right)$ and the efficiency of protein synthesis (kRNA), ie rate of synthesis relative to RNA, were calculated in order to explain protein synthesis variations.

The influence of lysine supplementation was studied on skeletal muscle protein turnover. This tissue is the main reservoir of body protein. Therefore, any change in protein turnover in skeletal muscle may explain variations in whole-body protein synthesis and breakdown.

\section{MATERIALS AND METHODS}

\section{Growth test}

Male broilers (Shaver-France) 120-day-old were reared in collective battery cages. At 4 days of age they were weighed, placed in individual cages and fed one of 5 experimental diets each differing in lysine content $(6.5,7.7$, $8.9,10.1$ and $11.3 \mathrm{~g} / \mathrm{kg}$ ). All diets were isoenergetic (3 $100 \mathrm{kcal} \mathrm{ME} / \mathrm{kg}$ ) and had the same protein content $(20 \%)$. They were in pellet form and formulated by supplementing a basal diet of corn-peanut meal type with increasing doses of L-lysine $\mathrm{HCl}$. Individual food intake and growth rate were recorded from 4-21 days of age.

\section{Measurement of protein turnover}

Protein synthesis measurements were performed in 3-week-old birds; 5 chickens per treatment were used. The birds were weighed after a 3-h fast. They were injected with $1 \mathrm{ml} / 100 \mathrm{~g}$ body weight of $\mathrm{L}-\left[4-{ }^{3} \mathrm{H}\right]$ phenylalanine solution (final concentration: $120 \mu \mathrm{mol} / \mathrm{ml}$, specific activity: $0.33 \mu \mathrm{Ci} / \mu \mathrm{mol}$ or $12.21 \mathrm{MBq} / \mathrm{mM}$ ).

Fifteen min after injection, birds were killed by an intracardiac injection of sodium pentobarbitone. An approximately $5 \mathrm{~g}$ sample of breast muscle (pectoralis major) was removed, immedi- ately frozen in liquid nitrogen and stored at -20 ${ }^{\circ} \mathrm{C}$ until analysis.

To determine the free and protein-bound phenylalanine specific activities, frozen muscle samples were ground in liquid nitrogen. To $1.5 \mathrm{~g}$ of the powder obtained, $5 \mathrm{ml}$ of perchloric acid (2\%) were added. The homogenate was centrifuged at $1800 \mathrm{~g}$ for $20 \mathrm{~min}$. The supernatant was then neutralized with $0.8-1 \mathrm{ml}$ of saturated potassium citrate solution (final $\mathrm{pH}=6.4$ ). The sample was centrifuged at $2000 \mathrm{~g}$ for $15 \mathrm{~min}$. The specific radioactivity of free phenylalanine was measured in the supernatant. The pellet containing protein was washed 3 times with 10 $\mathrm{ml}$ perchloric acid, homogenized with $10 \mathrm{ml}$ $0.3 \mathrm{M} \mathrm{NaOH}$ and incubated for $1 \mathrm{~h}$ at $37^{\circ} \mathrm{C}$. Protein-bound phenylalanine was obtained after protein reprecipitation with perchloric acid and subsequent hydrolysis with $6 \mathrm{~N} \mathrm{HCl}$ for $16 \mathrm{~h}$ at $100{ }^{\circ} \mathrm{C}$. Hydrochloric acid was then removed from the hydrolysate by evaporation.

In order to separate labelled phenylalanine from other radioactive amino acids, ie tyrosine, phenylalanine was converted into $\beta$-phenylethylamine (Garlick et al, 1980). The samples containing free amino acids and hydrolysates were incubated with L-tyrosine decarboxylase and pyridoxal phosphate overnight at $37^{\circ} \mathrm{C}$. $\beta$-Phenylethylamine was extracted by addition of sodium hydroxide and heptane. Sulfuric acid $(0.01 \mathrm{M})$ was then added to the supernatant. The radioactivity was measured by liquid scintillation (Tricarb 460, Packard). The assay of $\beta$-phenylethylamine was performed by fluorospectrometry $(495 \mathrm{~nm}$ emission, $390 \mathrm{~nm}$ excitation) using ninhydrin and L-leucylalanine (Suzuki and Yagi, 1976).

The fractional rate of protein synthesis $\left(K_{\mathrm{s}}\right.$, in $\% / d$ ) was calculated according to the formula given by McNurlan et al (1979):

$$
K_{\mathrm{s}}=\frac{S_{\mathrm{B}} \times 100}{S_{\mathrm{A}} \times t}
$$

where $S_{\mathrm{B}}$ and $S_{\mathrm{A}}$ are the protein-bound and the tissue homogenate free phenylalanine specific activities respectively, and $t$ is the incorporation time expressed in days.

In order to determine protein deposition, the whole muscle was carefully dissected from 19 and 23-day-old-birds. Daily protein growth rates 
$\left(K_{\mathrm{g}}\right)$ in the pectoralis major were determined as the percentage of the protein mass gained between these 2 ages. Muscle protein content was assessed with the Folin phenol reagent (Lowry et al, 1951).

The fractional rate of protein degradation ( $K_{\mathrm{d}}$, in $\% / d$ ) was obtained by subtracting the fractional growth rate $\left(K_{\mathrm{g}}\right.$, in $\left.\% / \mathrm{d}\right)$ from $K_{\mathrm{s}}$. RNA content was determined from the UV absorbance of the supernatant at $260 \mathrm{~nm}$ with a correction for peptide material base on the UV absorbance at $232 \mathrm{~nm}$, as described by Munro and Fleck (1969). The efficiency of protein synthesis, ie rate of synthesis relative to RNA ( $\mathrm{mg}$ of protein synthesized/day per mg of RNA) was obtained from the formula $\mathrm{kRNA}=\left(K_{\mathrm{s}} \times 10\right) / C_{\mathrm{s}}$ where $C_{\mathrm{s}}$ is the capacity for protein synthesis, ie RNA/protein ratio ( $\mu \mathrm{g}$ of $\mathrm{RNA} / \mathrm{mg}$ of protein).

The total amount of protein synthesized or degraded in the pectoralis major muscle was calculated by multiplying the respective protein fractional rate $\left(K_{\mathrm{s}}\right.$ or $\left.K_{\mathrm{d}}\right)$ by the muscle protein mass. Absolute rates of protein synthesis or breakdown in breast muscle were expressed on a metabolic weight basis $\left(\mathrm{kg}^{0.75}\right)$.

All results were expressed as means $\pm \mathrm{SE}$. Analysis of variance was carried out to assess the significance of the effect of amino acid supplementation, and Student's $t$-test was used to assess the significance of differences between means (Snedecor and Cochran, 1971).

\section{RESULTS AND DISCUSSION}

\section{Growth performance}

On the day of the experiment, chickens weighed between $199 \pm 8$ and $465 \pm 25 \mathrm{~g}$ ( $n=13$ ) according to the diet (table 1 ). Their food intake increased by $116 \%$ with increasing dietary lysine content. The growth rates are given for 2 groups of animals: birds used for protein synthesis measurements ( $K_{\mathrm{s}}$ Expt) and those used for protein deposition determination $\left(K_{\mathrm{g}}\right.$ Expt) (table I). There was no significant difference between groups fed the same diet. By contrast, the growth rate of chickens was affected by the diet and was directly related to dietary lysine content, at least between 0.65 and $1.01 \%$ of lysine in the diet.

Increasing the dietary lysine content enhanced weight gain and reduced feed: gain ratio (fig 1). Both linear and quadratic polynomial regressions $\left(R^{2}=0.99\right.$ and 0.95 for weight gain and feed: gain ratio respectively) were highly significant. For the

Table I. Effects of lysine supplementation on body weight, growth rate and food intake in 3-week-old chickens $(n=13)$.

\begin{tabular}{lllll}
\hline $\begin{array}{l}\text { Lysine } \\
\text { (\% } \\
\text { in the diet) }\end{array}$ & $\begin{array}{l}\text { Body wt } \\
(\mathrm{kg})\end{array}$ & \multicolumn{2}{c}{ Growth rate * $(g / d)$} & $\begin{array}{l}\text { Food intake } \\
(g / d)\end{array}$ \\
\cline { 3 - 4 } & & $\mathrm{K}_{\mathrm{s}}$ Expt & $\mathrm{K}_{\mathrm{g}}$ Expt & \\
\hline & & & & \\
0.65 & $199 \pm 8^{\mathrm{a}}$ & $12.16 \pm 0.54^{\mathrm{a}}$ & $11.52 \pm 0.83^{\mathrm{a}}$ & $25.13 \pm 1.12^{\mathrm{a}}$ \\
0.77 & $296 \pm 8^{\mathrm{b}}$ & $22.76 \pm 0.78^{\mathrm{b}}$ & $19.26 \pm 1.40^{\mathrm{b}}$ & $38.42 \pm 1.45^{\mathrm{b}}$ \\
0.89 & $422 \pm 19^{\mathrm{c}}$ & $31.10 \pm 2.05^{\mathrm{c}}$ & $32.45 \pm 1.34^{\mathrm{c}}$ & $55.02 \pm 2.66^{\mathrm{c}}$ \\
1.01 & $465 \pm 25^{\mathrm{c}}$ & $32.58 \pm 3.22^{\mathrm{c}}$ & $35.12 \pm 1.17^{\mathrm{c}}$ & $58.79 \pm 2.14^{\mathrm{c}}$ \\
1.13 & $456 \pm 27^{\mathrm{c}}$ & $33.70 \pm 3.71^{\mathrm{c}}$ & $31.95 \pm 4.12^{\mathrm{c}}$ & $54.37 \pm 3.33^{\mathrm{c}}$
\end{tabular}

Values are means \pm SE. Mean within a column not sharing a common subscript were significantly different $(P<0.05)$. Birds in $K_{\mathrm{S}}$ Expt $(n=8)$ or in $K_{\mathrm{g}}$ Expt $(n=5)$ were used for measurement of protein synthesis and deposition respectively. No difference was significant between $K_{\mathrm{s}}$ and $K_{\mathrm{g}}$ groups fed the same diet $(P>0.05)$. 

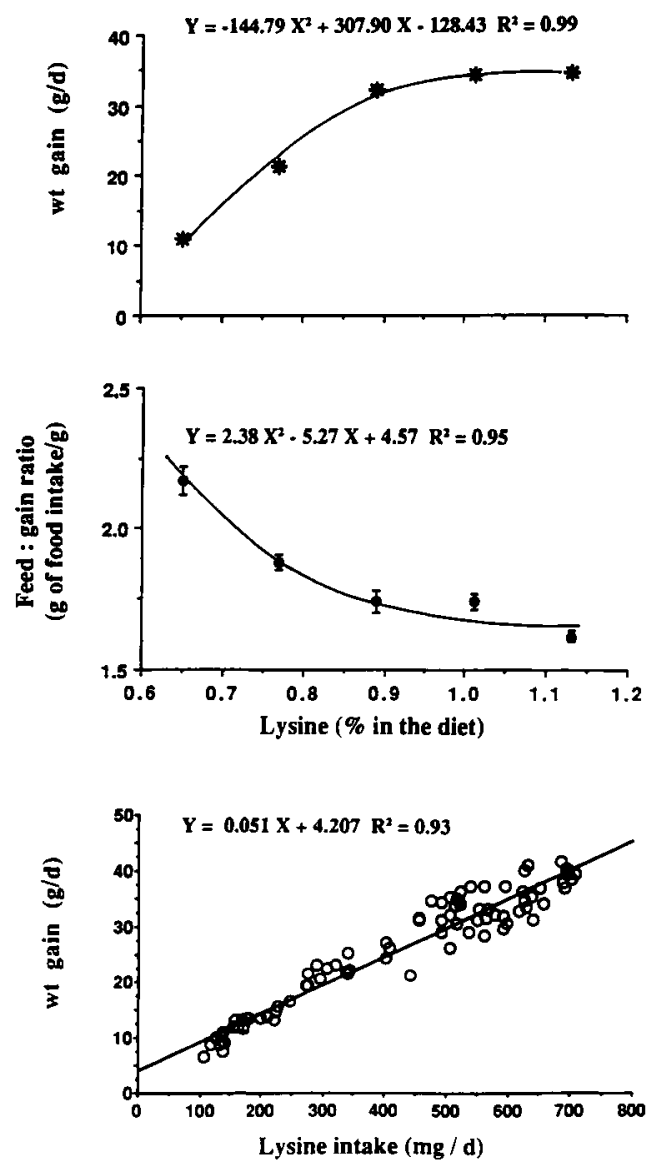

Fig 1. Elfect of lysine supplementation on growth performances of chicks fed a $20 \%$ protein diet.

weight gain, the correlation was also high $\left(R^{2}=0.93\right)$ when the results were expressed in relation to lysine intake.

These data confirmed that a dietary lysine content of $6.5 \mathrm{~g} / \mathrm{kg}$ is not adequate for optimal growth in chickens. Maximum growth rate was obtained with a dietary lysine content $>9 \mathrm{~g} / \mathrm{kg}$. This result is in good agreement with previous estimates of lysine requirements in growing broilers
(Larbier and Blum, 1979; Azcona et al, 1986).

\section{Protein turnover}

The injection of a large amount of amino acid combined with a tracer-dose of the same labelled amino acid floods free amino acid pools leading to similar plasma and tissue specific activities (Henshaw et al, 1971). In the rat, the free specific activity measured in liver and muscle and that found in the plasma are similar and fairly constant (Garlick, 1980). In addition, the incorporation of the label is measured within a few minutes post-injection. Thus, complex variations in specific radioactivities are avoided and label recycling is minimized.

Muramatsu et al $(1985,1986)$ previously validated the use of a [ $\left.{ }^{3} \mathrm{H}\right]$ phenylalanine flooding-dose injection in chickens. In our studies, the muscle free $\left[{ }^{3} \mathrm{H}\right]$ phenylalanine specific radioactivity measured $15 \mathrm{~min}$ after injection was at least equal to $81 \%$ of the injected specific radioactivity (data not shown), suggesting that the procedure was efficient to flood free phenylalanine pools.

The aim of our experiments was to study the effect of a dietary lysine imbalance on protein metabolism and to determine whether the increase in protein deposition was achieved through changes in the rate of protein synthesis or degradation, or both.

The fractional rates of protein synthesis, growth and degradation $\left(K_{\mathrm{s}}, K_{\mathrm{g}}, K_{\mathrm{d}}\right.$, expressed in $\% / d$ ) are given in table III. $K_{s}$ and $K_{d}$ values obtained in chickens fed a well-balanced diet were similar to those obtained by Muramatsu et al (1985) in growing chickens.

From 0.65 up to $0.89 \%$ dietary lysine, there were no significant differences in 
fractional protein synthesis rates. However, $K_{\mathrm{s}}$ rate decreased significantly when the dietary lysine concentration exceeded $0.90 \%$, and was in the range of $66-73 \%$ of those measured in lysine deficient diets. By contrast, the fractional protein degradation rate $\left(K_{\mathrm{d}}\right)$ decreased progressively when the lysine content of the diet increased, ie when the quality of protein intake (amino acid balance) was improved. This effect is consistent with several studies (reviewed by McNurlan and Garlick, 1989) in which amino acids have been consistently reported to inhibit protein breakdown.

Our experiments were performed without pair-fed animals (food intake varied from 25 to $59 \mathrm{~g} /$ day; table I). In similar experiments performed in rats, Roeder and Broderick (1981) observed that the addition of lysine and threonine to wheat gluten resulted in a $50 \%$ increase in voluntary food intake, and reported an increase in both the protein fractional synthesis and degradation rates after 10 days of experimental diets. Therefore, it is not possible as in our experiments, to determine to what extent these variations resulted from the improvement in protein quality per se, or from the accompanying alterations in protein or non protein energy intake. In our experiment, however, the food intake/body weight ratio was similar between groups fed the different diets. Consequently, this may explain why the fractional protein synthesis rate did not change from 0.65 up to $0.89 \%$ dietary lysine. Indeed, $K_{\mathrm{s}}$ remained unchanged because the decline in ribosomal capacity $C_{\mathrm{s}}$ was cancelled by an increase in the protein synthetic efficiency kRNA (table III). The reduction in $C_{\mathrm{s}}$ observed when lysine supplementation in the diet increases was due to an enhancement in muscle protein content, although RNA content slightly decreased (table II). The low kRNA value recorded with the $0.65 \%$ lysine-deficient diet was in accordance with previous studies. It has been shown recently in hepatocytes that deprivation of single essential amino acids resulted in an inhibition of protein synthesis through a defect in initiation, a key step in the translation process (Everson et al, 1989).

Table II. Effects of lysine supplementation on weight, protein and RNA contents of the pectoralis major muscle in 3-week-old chickens $\left(K_{\mathrm{s}}\right.$ Expt).

$\begin{array}{llll}\text { Lysine } & \text { Muscle weight * } & \text { Protein content } & \text { RNA content } \\ (\% \text { in the diet }) & (g) & (\mathrm{mg} / \mathrm{g}) & (\mathrm{mg} / \mathrm{g})\end{array}$

\begin{tabular}{lrll}
$\begin{array}{l}\text { (\% in the diet }) \\
\text { ( }\end{array}$ & $(\mathrm{g})$ & $(\mathrm{mg} / \mathrm{g})$ & $\begin{array}{l}\text { RNA content } \\
(\mathrm{mg} / \mathrm{g})\end{array}$ \\
\hline & & & \\
0.65 & $3.25 \pm 0.25^{\mathrm{a}}$ & $114.39 \pm 3.15^{\mathrm{a}}$ & $2.000 \pm 0.241^{\mathrm{a}}$ \\
0.77 & $5.78 \pm 0.20^{\mathrm{b}}$ & $119.45 \pm 2.73^{\mathrm{a}}$ & $1.365 \pm 0.047 \mathrm{bc}$ \\
0.89 & $8.97 \pm 0.39^{\mathrm{c}}$ & $121.78 \pm 4.18^{\mathrm{ac}}$ & $1.207 \pm 0.056^{\mathrm{bc}}$ \\
1.01 & $12.11 \pm 0.48^{\mathrm{d}}$ & $131.29 \pm 5.75^{\mathrm{bc}}$ & $1.055 \pm 0.046 \mathrm{c}$ \\
1.13 & $14.27 \pm 0.41^{\mathrm{e}}$ & $145.84 \pm 1.16^{\mathrm{b}}$ & $1.526 \pm 0.030 \mathrm{~b}$
\end{tabular}

Values are means $\pm S E(n=5)$. Means within a column not sharing a common subscript were significantly different $(P<0.05)$. "These values are not actual muscle weights of chickens used in $K_{\mathrm{s}}$ experiments because they were not carefully dissected. They were individually estimated from the body weights of $K_{\mathrm{s}}$ Expt birds and the respective allometric relations (linear regressions between muscle $v s$ body weights) determined from each group of chickens used for protein deposition determination. 
Table IIl. Effects of lysine supplementation on fractional rates of protein turnover $\left(K_{\mathrm{s}}, K_{\mathrm{g}}, K_{\mathrm{d}}\right)$ ribosomal capacity $C_{s}$ ( $\mu \mathrm{g}$ of RNA/mg of protein) and protein synthetic efficiency kRNA (mg of protein synthesized/day per $\mathrm{mg}$ of RNA) in the pectoralis major muscle of 3-week-old chickens.

\begin{tabular}{|c|c|c|c|c|c|}
\hline \multirow{2}{*}{$\begin{array}{l}\text { Lysine } \\
(\% \text { in the diet) }\end{array}$} & \multicolumn{3}{|c|}{ Fractional rates $(\% / d)$} & \multirow{2}{*}{$\begin{array}{l}\mathrm{C}_{s} \\
(\mu g / m g)\end{array}$} & \multirow{2}{*}{$\begin{array}{l}\text { kRNA } \\
(m g / m g \text { per } d)\end{array}$} \\
\hline & $\mathrm{K}_{s}$ & $\mathrm{~K}_{g}$ & $\mathrm{~K}_{d}$ & & \\
\hline 0.65 & $36.84^{a}$ & 3.80 & 33.04 a & $17.4^{a}$ & $22.1 \mathrm{a}$ \\
\hline 0.77 & $34.37^{\mathrm{a}}$ & 6.60 & $27.77^{b}$ & $11.5^{b}$ & $30.2 b c$ \\
\hline 0.89 & $35.54^{a}$ & 9.96 & $25.58^{b}$ & 9.9 be & $36.1^{b}$ \\
\hline 1.01 & $25.90^{b}$ & 6.12 & $19.78^{c}$ & $7.7 \mathrm{ce}$ & $36.2^{b^{*}}$ \\
\hline 1.13 & $23.60^{b}$ & 5.80 & $17.80^{\mathrm{c}}$ & 10.5 be & 22.6 ac \\
\hline SEM & 2.43 & 2.48 & 2.75 & 1.1 & 2.9 \\
\hline
\end{tabular}

Means within a column not sharing a common subscript were significantly different $(P<0.05)$. " Missing value.

When dietary lysine concentration exceeded $0.9 \%$ and consequently reached levels greater than that required for maximal growth, there was a decrease in the fractional protein synthesis rate. Laurent et al (1984) reported a similar observation in rats fed with protein intake at levels in excess of that required for maximal growth. Our findings clearly indicated that the decrease in $K_{\mathrm{s}}$ values was primarily explained by an impairment in ribosomal efficiency (kRNA), as also observed in skeletal muscles of rats fed a high protein intake (D Taillandier, unpublished data).

The absolute rates of protein synthesis and degradation in the pectoralis major muscle are presented in figure $2 a$. Since the groups of animals fed varying lysine intakes had different skeletal muscle protein mass and body weight, data were not similar when expressed in absolute (fiy 2a) or fractional (fig $2 b$ ) protein turnover rates. Increasing lysine supplementation in the diet resulted in increased protein deposition. This was due to significant increases in both absolute rates of protein synthesis and degradation. Protein deposition was maximum for $0.89-1.01 \%$ lysine in the diet. Our results are consistent with those of Salter et al (1990) in growing pigs.
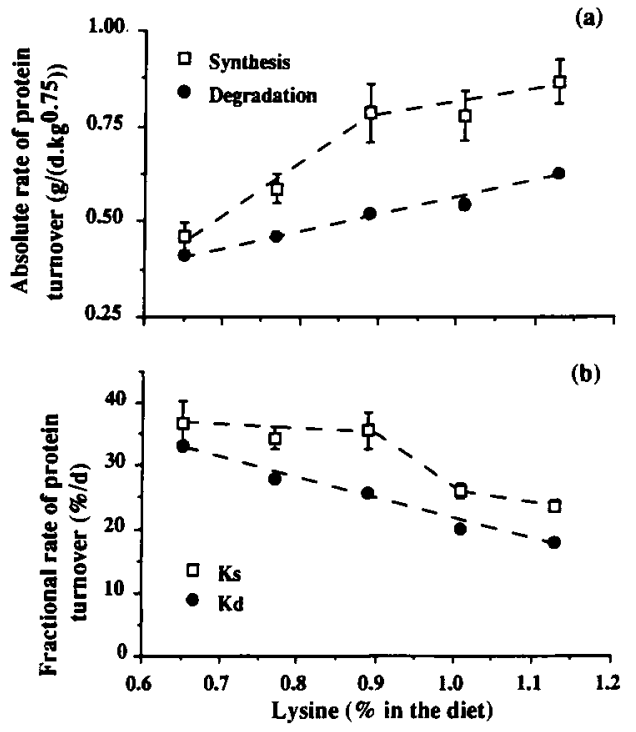

Fig 2. Effect of lysine supplementation on the absolute (a) and fractional (b) rates of protein synthesis and degradation in the pectoralis major muscle. (Bars represent SE). 
These authors showed that the increase in protein deposition observed with dietary supplementation of lysine was due to a greater increase in the rate of protein synthesis than in the degradation rate. In addition, increasing lysine supplementation in excess of the requirement led to no further significant increases in protein synthesis or degradation, and therefore did not affect protein deposition. However, a different conclusion was reached by Fuller et al (1987) in experiments with growing pigs. When the protein quality of a lysinedeficient diet was improved by lysine supplementation, nitrogen retention and protein deposition increased, without any significant changes in protein synthesis or degradation.

In conclusion, a dietary subdeficiency in an essential amino acid (eg lysine) reduced growth rate and protein deposition in the chicken. The efficiency of protein deposition (ie $\left.\left(100 \times K_{\mathrm{g}}\right) / K_{\mathrm{s}}\right)$ was 10.31 , $19.20,28.02,23.63$ and $24.58 \%$ for dietary lysine contents of $6.5,7.7,8.9,10.1$ and $11.3 \mathrm{~g} / \mathrm{kg}$ respectively. There was a maximum for a dietary lysine content of about 9 $\mathrm{g} / \mathrm{kg}$, a value close to the optimum requirement, when the efficiency of protein synthesis kRNA was maximum.

\section{ACKNOWLEDGMENT}

The authors gratefully acknowledge the help of A Aumaitre for his supervision of this paper.

\section{REFERENCES}

Arnal M, Obled C, Attaix D, Patureau Mirand P, Bonin D (1987) Dietary control of protein turnover. Diabète Metab (Paris) 13, 630-642

Azcona JO, Larbier M, Chagneau AM (1986) Emploi des acides aminés radioactifs pour estimer le besoin alimentaire en lysine du poulet. In: 7th Conf Eur Avicult. Larbier, Paris, 364-368

Everson WV, Flaim KS, Susco DM, Kimball SR, Jefferson LS (1989) Effect of amino acid deprivation on initiation of protein synthesis in rat hepatocytes. Am J Physiol 256, C18-C27

Fuller MF, Reeds PJ, Cadenhead A, Seve B, Preston T (1987) Effect of the amount and quality of dietary protein on nitrogen metabolism and protein turnover of pigs. $\mathrm{Br} J$ Nutr $58,287-300$

Garlick PJ (1980) Assessment of protein metabolism in the intact animal. In: Protein Deposition in Animals (Buttery PJ, Lindsay DB, eds) Butterworths, London

Garlick PJ, McNurlan MA, Preedy VR (1980) A rapid convenient technique for measuring the rate of protein synthesis in tissues by injection of $\left[{ }^{3} \mathrm{H}\right]$-Phe. Biochm J 192, 719-723

Henshaw EC, Hirsch CA, Morton BE, Hiatt HH (1971) Control of protein synthesis in mammalian tissues through changes in ribosome activity. J Biol Chem 246, 436-446

Larbier M, Picard M (1977) Free lysine concentration in skeletal muscle of chicks for estimating the availability of lysine in fish meals. Archiv Geflügelkd 41, 87-91

Larbier M, Blum JC (1979) Valeur nutritionnelle de la $\Sigma N$-acetyl-lysine comparée à celle de la L-lysine monochlorhydrate chez le poulet. Archiv Geflügelkd 43, 238-241

Laurent BC, Moldawer LL, Young VR, Bistrian BR, Blackburn GL (1984) Whole-body leucine and muscle protein kinetics in rats fed varying protein intakes. Am J Physiol 246, E444-E451

Lowry OH, Rosebrough NJ, Farr AL, Randall RJ (1951) Protein measurement with the folin phenol reagent. J Biol Chem 193, 265-275

Maruyama K, Sunde ML, Swick RW (1978) Growth and muscle protein turnover in the chick. Biochem J 176, 573-582

McDonald ML, Swick RW (1981) The effect of protein depletion and repletion on muscle protein turnover in the chick. Biochem $J 194$, 811-819

McNurlan MA, Tomkins AM, Garlick PJ (1979) The effect of starvation on the rate of protein synthesis in rat liver and smail intestine. Biochem J 178, 373-379 
McNurlan MA, Garlick PJ (1989) Influence of nutrient intake on protein turnover. Diabetes/ Metab Rev 5, 165-189

Munro HN, Fleck A (1969) Analysis of tissues and body fluids for nitrogenous constituents. $\mathrm{In}$ : Mammalian Protein Metabolism (Munro HN, ed) Academic Press, New York, vol III, 424-525

Muramatsu T, Okumura J (1985) Whole body protein turnover in chicks at early stages of growth. J Nutr 115, 483-490

Muramatsu T, Kato M, Tasaki I, Okumura J (1986) Enhanced whole-body protein synthesis by methionine and arginine supplementation in protein-starved chicks. Br J Nutr 55, 635-641

Roeder RA, Broderick GA (1981) Effect of dietary protein quality on fractional rates of mus- cle protein synthesis and catabolism in the rat. Nutr Rep Int 24, 361-369

Salter DN, Montgomery Al, Hutson A, Quelch DB, Elliot RJ (1990) Lysine requirements and whole-body protein turnover in growing pigs. Br J Nutr 63, 503-513

Snedecor GW, Cochran WG (1971) Méthodes Statistiques. Assoc Coord Agric, Paris, 6th edn

Suzuki O, Yagi K (1976) A fluorometric assay for phenylethylamine in rat brain. Anal Biochem 75, 192-200

Waterlow JC (1984) Protein turnover with special reference to man. $Q J$ Exp Physiol (Lond) $69,409-438$ 